\section{RAC defers to NIH director on some gene therapy cases}

\begin{abstract}
Washington. The recombinant DNA advisory committee (RAC) of the National Institutes of Health (NIH) - a panel of lawyers, physicians and researchers charged with reviewing human gene therapy protocols last week voted overwhelmingly to let the NIH director decide whether it is appropriate to bypass the committee in reviewing requests for the use of human gene therapy to treat individual patients.
\end{abstract}

The new measures were adopted at a hastily convened meeting of the RAC at which the NIH director, Bernadine Healy, defended her decision last month to deviate from normal procedures and grant permission to Ivor Royston of the San Diego Regional Cancer Center to treat a single patient with an otherwise untreatable brain tumour using an experimental gene-therapy procedure. Although RAC says that a full review remains the preferred course of action, an expedited review mechanism may be used when a patient's condition is too grave to wait for the full committee to consider it.

RAC members voted by nine to three, with one abstention, in favour of allowing the NIH director to make such decisions. Although most RAC members feel that NIH, like the US Food and Drug Administration, needs such a short cut, several members expressed concern that such a measure, by eliminating open discussion, will undermine the review process. They also feel that the field of gene therapy is still too new to forgo this level of public and scientific scrutiny.

A. Dusty Miller of the Fred Hutchinson Cancer Research Center, one of three RAC members to vote against it, complained that the RAC had "no room to move" because it acts in only an advisory capacity to the NIH director. "I don't like the idea of having a

\section{Press, Mullis win Japan Prize}

Tokyo. Two US scientists have won this year's Japan Prize, Japan's answer to the Nobel prize. Frank Press, president of the US National Academy of Sciences, wins the $¥ 50$-million (US\$400,000) award for his
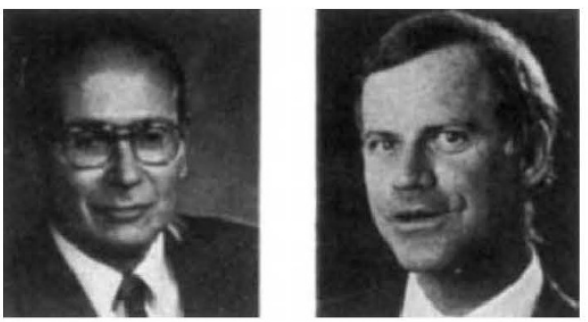

Frank Press (left) and Kary Mullis political appointee review these proposals and make decisions on them", says Miller (see page 195). RAC member Abbey Meyers, executive director of the National Organization for Rare Disorders, fears that two sets of standards will now emerge: one for pressure groups with political clout, representing people with AIDS and cancer, and another for more "politically unimportant" diseases.

The issue arose in early October last year when Senator Tom Harkin (Democrat, Iowa) wrote to Healy on behalf of a 51-year-old former constituent suffering from a lifethreatening stage-IV glioblastoma that was unresponsive to conventional treatments. Harkin asked Healy to consider granting Royston permission to treat the patient with an experimental gene-therapy procedure. Healy replied that there were not enough studies to consider using the therapy on a compassionate-plea basis and suggested that the patient be evaluated at NIH where an approved brain tumour therapy protocol was already under way. The patient rejected that approach because it would have required further brain surgery.

Royston's protocol was informally discussed at the RAC meeting on 4 December but not voted upon because adequate public notice had not been given, and the required review materials were incomplete. In view of the patient's deteriorating condition and in the absence of a mechanism for expedited review (RAC meets four times a year), Healy, after consulting NIH officials, gave Royston the go ahead on 28 December - the day that FDA also approved the protocol.

On 4 January, Royston began treating the patient with her own tumour cells, which have been genetically modified to express and secrete interleukin-2 (IL-2) in the hope of stimulating an anti-tumour immune response.

Diane Gershon

contributions to seismological research and disaster mitigation. The other prize goes to Kary Mullis, a private consultant in nucleic acid chemistry, for his development of the polymerase chain reaction used for amplifying DNA sequences.

The Japan Prize was launched in 1985 to reward scientists and engineers who have made important practical contributions to society. The awards are made in different fields each year. Although intended to complement the Nobel Prize, which usually recognizes more basic research, the Japan Prize is not well-known outside Japan. The prize will be presented in Tokyo on 28 April.

David Swinbanks

\section{Tokyo University opens itself to outside scrutiny}

Tokyo. In a move that could have profound long-term consequences for research at Japan's national universities, Tokyo University was host last week to a team of eminent Western and Japanese scientists carrying out an external review of the university's physics department. This is the first-ever such review in Japan and is part of a growing movement to make Japan's universities more accountable to outsiders.

The review was initiated by Tokyo University president Akito Arima and science dean Ikuo Kushiro (see Nature 360, 403; 1992). Four reviewers live outside the country: Sydney Brenner of the University of Cambridge School of Medicine in Britain, David Pines of the University of Illinois, Yoichiro Nambu of the University of Chicago and Jean Audouze, science adviser to the French government. They were joined by several Japanese scientists, including Nobel prizewinner Leo Esaki, president of Tsukuba University; Minoru Oda, president of RIKEN; Junjiro Kanamori, president of Osaka University; and Hiroshi Takuma of the University of Electro-communications.

The reviewers, working in small groups, spent an afternoon and the next morning visiting laboratories doing research ranging from high-energy physics to genetic and molecular biological studies in biophysics. They also held a meeting attended only by younger researchers that, in the words of one department member, was "quite lively and lasted a long time". After reviewing financial matters, the team spent a day discussing what they had learned.

The reviewers were interested not just in science but also in grants, student recruitment and working conditions. Their presence has already had a "very good influence", says one department scientist, "forcing us to straighten up our thinking about what we are doing".

The reviewers are expected to submit their findings in about a month to Arima, who retires as president at the end of March. Arima says he does not know if the review process will be extended to other departments, but a senior official of the Ministry of Education, Science and Culture says that he expects Arima's successor to carry on the review process. University departments of lesser quality than the physics department at Tokyo University are expected to oppose the idea, but they may find themselves swept up in a tide of reform they cannot stop.

Researchers at Tokyo University do not expect immediate changes as a result of the review. "But in the long run I think it will affect the research system and the allocation of money", says one member of the department.

David Swinbanks 